\title{
Modulation of airway inflammation and resistance in mice by a nicotinic receptor agonist
}

\author{
M-R. Blanchet, E. Israël-Assayag and Y. Cormier
}

ABSTRACT: Nicotinic agonists, including 1,1-dimethyl-4-phenylpiperazinium (DMPP), have antiinflammatory properties and in some instances smooth muscle relaxing effects. Since inflammation and airway smooth muscle contraction are two major components of asthma, the present authors investigated the effects of DMPP on airway inflammation and airway resistance in a mouse model of asthma.

Mice were sensitised and challenged with ovalbumin (OVA) and treated either intraperitoneally or intranasally with DMPP. The effect of DMPP was tested on airway inflammation, airway resistance and on the increase of intracellular calcium in bronchial smooth muscle cells.

DMPP given either during sensitisation, OVA challenges or throughout the protocol prevented lung inflammation and decreased the serum level of OVA specific immunoglobulin E. DMPP administration reduced the number of total cells, lymphocytes and eosinophils in the bronchoalveolar lavage (BAL) fluid. Intranasal DMPP administration was as effective as dexamethasone (DEXA) in reducing total cell count and eosinophil counts in BAL fluid. DMPP, but not DEXA, reduced tissue inflammation. Intranasal DMPP, given $\mathbf{1 0}$ min before the test, reduced airway responsiveness to metacholine. DMPP also reduced the increase in intracellular calcium in response to bradykinin.

In conclusion, these results show that 1,1-dimethyl-4-phenylpiperazinium reduces lung inflammation and prevents airway hyperresponsiveness in the mouse model of asthma.

KEYWORDS: Airway resistance, asthma, inflammation, intracellular calcium, nicotinic receptor agonists

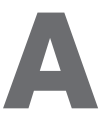
sthma is characterised by airway inflammation, hyperresponsiveness and remodelling [1]. Lymphocytes, alveolar macrophages and eosinophils are involved in the development and persistence of the disease [2-4]. Many cytokines, including interleukin (IL)4, IL-5 and IL-13 play an important role in asthma [1]. In recent years, drugs combining antiinflammatory and bronchodilator effects have been developed for the treatment of asthma.

Inflammatory and structural cells involved in the pathophysiology of asthma express a variety of receptors, including nicotinic acetylcholine receptors (nAChRs) [5-7]. The role of nAChRs on these cells is not fully understood. Nicotinic agonists have anti-inflammatory effects both in vitro and in vivo. In animal models, nicotine, a nicotinic receptor agonist, inhibits the development of inflammatory diseases such as type I diabetes [8] and hypersensitivity pneumonitis [9]. In humans, nicotine is effective in the treatment of ulcerative colitis [10]. In vitro, nicotine reduces the release of IL-1 $\beta$ and tumour necrosis factor (TNF), and the activity of thromboxane synthetase in alveolar macrophages [11]. Nicotine also blocks lymphocytes in the G0/G1 phase of the cell cycle and affects the intracellular signalling cascade activated by the stimulation of the T-cell receptor [12]. Nicotine reduces lymphocyte proliferation [13] and the expression of the CD28 costimulatory molecule on T-cells [14] and B7 molecules on alveolar macrophages [9]. B7 molecules are involved in the complete activation of lymphocytes by alveolar macrophages and blockade of this costimulatory pathway reverses the manifestations of asthma in a mouse model [15].

Although nicotine has interesting anti-inflammatory properties, it causes addiction due to its lipophilic properties, which allow it to cross the blood-brain barrier; 1,1-dimethyl-4-phenylpiperazinium (DMPP) is a more hydrophilic synthetic

\section{AFFILIATIONS}

Unité de Recherche, Centre de Pneumologie de l'Hôpital Laval, Institut Universitaire de Cardiologie et de Pneumologie de l'Université Laval, Québec, Canada.

CORRESPONDENCE

Y. Cormier

Hôpital Laval

2725 Chemin Ste-Foy

Québec City

Québec

Canada G1V 4G5

Fax: 14186564762

E-mail: yvon.cormier@med.ulaval.ca

Received

October 072004

Accepted after revision:

April 042005 
nAChRs ligand. This molecule does not readily cross the brainblood barrier and, therefore, should not cause addiction [16]. DMPP reduces the release of IL-1 and TNF from isolated spleen cells [17], and the release of TNF and IL-6 from macrophages [18]. DMPP also reduces the bronchomotor tone induced by histamine in cats [19].

As nAChRs are expressed in cells involved in the development of asthma and since their agonists have anti-inflammatory and bronchodilator effects in vitro, the current authors' hypothesised that some nAChRs agonists could have interesting antiasthmatic properties. To verify this hypothesis, the effects of DMPP on airway inflammation and airway responsiveness in vivo were tested in a mouse model of asthma, compared with the effects of dexamethasone (DEXA), and possible mechanisms of action were considered.

\section{METHODS}

\section{Asthma induction and assessment of lung inflammation}

The protocols were approved by the institutional ethics committee (Laval Hospital, Ste-Foy, Quebéc, Canada) and conducted according to the Helsinki convention. Balb/c female mice, 18-20 g, (Charles River, Québec, Canada) were sensitised with $50 \mu \mathrm{g}$ chicken ovalbumin (OVA) conjugated to $2 \%$ aluminium hydroxide in $100 \mu \mathrm{L}$ saline given intraperitoneally (i.p.). Control mice were injected with saline. For the challenges, mice were anaesthetised with 3\% isoflurane, intranasally (i.n.) challenged with $50 \mu \mathrm{l}$ of $1.5 \%$ OVA or saline (fig. 1).

Description of the timing for the treatments is presented in table 1. In protocol number 1, mice were treated i.p. with DMPP at doses ranging from $0.01-0.5 \mathrm{mg} \cdot \mathrm{kg}^{-1}$ during the OVA challenge period. In protocol number 2 , mice were treated i.p. with $0.5 \mathrm{mg} \cdot \mathrm{kg}^{-1}$ DMPP either during sensitisation (2A), challenge (2B) or throughout the protocol (2C). In protocol number 3, mice were treated with $2.0 \mathrm{mg} \cdot \mathrm{kg}^{-1}$ i.n. DMPP (3A) or DEXA (3B) on days 21, 22 and 23 only. Appropriate positive and negative controls were carried out in parallel with the treated groups.

On day 24, mice were sacrificed by over-exposure to isoflurane, tracheotomised, and bronchoalveolar lavage (BAL) was performed. Total cells were counted and cytospin preparations were made. Differential counts were obtained by Diff-Quik ${ }^{\circledR}$ staining.

\section{OVA-specific Immunoglobulin E titre by ELISA}

On the day of the sacrifice, blood from protocol number 2 mice was collected via the orbital sinus (after anaesthesia with 3\% isoflurane). Serum OVA- specific immunoglobulin (Ig) E were measured as previously described [20], but with minor modifications; plaques were coated with anti-mouse IgE (BD Pharmingen, Missisauga, ON, Canada) and levels of OVA

\begin{tabular}{|c|c|c|c|c|c|c|}
\hline Days 1 & 7 & 14 & 21 & 22 & 23 & 24 \\
\hline$\uparrow$ & 4 & & 4 & 4 & 4 & $\uparrow$ \\
\hline OVA & OVA & & OVA & $\mathrm{VA}$ & OVA & SF \\
\hline
\end{tabular}

FIGURE 1. Schematic presentation of the mouse model of asthma. OVA: ovalbumin; SF: sacrifice. specific $\operatorname{IgE}$ were expressed in arbitrary units of optical density.

\section{Histopathology studies}

Lung sections from DMPP i.n. treated mice were fixed in Bouin's solution, embedded in paraffin, cut in $0.5-\mu \mathrm{m}$ sections, and stained with haematoxylin-eosin. Inflammatory parameters in lung tissue (peribronchial, perivascular and parenchymal infiltration of inflammatory cells) were evaluated blindly by a senior lung pathologist. Total histology score was calculated and graded from $0-4$, where $0=$ normal lung and $4=$ diffuse maximal inflammation.

\section{Assessment of airway resistance}

Sensitised mice were i.n. treated with $0.5 \mathrm{mg} \cdot \mathrm{kg}^{-1}$ of DMPP on day 24, $10 \mathrm{~min}$ prior to the metacholine (MCh) challenge (protocol number 4 as described in table 1), or on days 21, 22, 23 , and on day $24,10 \mathrm{~min}$ prior to the MCh challenge (protocol number 5). For comparison with DEXA, mice were treated with i.n. DMPP (protocol number 6A) or DEXA (protocol number $6 \mathrm{~B}$ ) at $2.0 \mathrm{mg} \cdot \mathrm{kg}^{-1}$ on days 21,22 and 23 , and on day 24, $10 \mathrm{~min}$ prior to the $\mathrm{MCh}$ challenge.

On day 25 , mice were anaesthetised with $10 \mathrm{mg} \cdot \mathrm{kg}^{-1}$ xylazine/ $5.85 \mathrm{mg} \cdot \mathrm{kg}^{-1}$ pentobarbital, tracheotomised and intubated with a $18 \mathrm{G}$ catheter. Airway resistance was measured with a Flexivent apparatus (SCIREQ, Montreal, Québec, Canada). Respiratory frequency was set at 160 breaths $\cdot \mathrm{min}^{-1}$ with a tidal volume of $0.2 \mathrm{~mL}$ and a positive end-expiratory pressure of 2-4 $\mathrm{mL} \mathrm{H}_{2} \mathrm{O}$ was applied. Increasing concentrations of $\mathrm{MCh}$ $\left(0-31.25 \mathrm{mg} \cdot \mathrm{kg}^{-1}\right)$ were administered via the jugular vein. Airway resistance was recorded every $15 \mathrm{~s}$ by a snapshot measure. Baseline resistance was restored before administering the subsequent doses of MCh.

\section{Intracellular calcium measurements}

A human bronchial smooth muscle cell line (BSMC; Cambrex Corporation, East Rutherford, NJ, USA), was used to verify the effect of DMPP on in vitro smooth muscle intracellular

TABLE 1 Description of the different study protocols

\begin{tabular}{ccccc}
$\begin{array}{l}\text { Protocol } \\
\text { number }\end{array}$ & $\begin{array}{c}\text { Drugs } \\
\text { used }\end{array}$ & $\begin{array}{c}\text { Route of } \\
\text { administration }\end{array}$ & $\begin{array}{c}\text { Doses } \\
\mathbf{m g} \cdot \mathbf{k g}^{-\mathbf{1}}\end{array}$ & $\begin{array}{c}\text { Days of } \\
\text { administration }\end{array}$ \\
\hline \multicolumn{4}{c}{ Assessment of airway inflammation } \\
1 & DMPP & i.p. & $0.01-0.5$ & $21,22,23$ \\
2A & DMPP & i.p. & 0.5 & $1-20$ \\
2B & DMPP & i.p. & 0.5 & $21,22,23$ \\
2C & DMPP & i.p. & 0.5 & $1-23$ \\
3A & DMPP & i.n. & 2 & $21-23 ; 24^{\#}$ \\
3B & DEXA & i.n. & 2 & $21-23 ; 24^{\#}$ \\
Assessment of airway resistance & & & \\
4 & DMPP & i.n. & 0.5 & $24^{\#}$ \\
5 & DMPP & i.n. & 0.5 & $21-23 ; 24^{\#}$ \\
$6 \mathrm{~A}$ & DMPP & i.n. & 2 & $21-23 ; 24^{\#}$ \\
$6 \mathrm{~B}$ & DEXA & i.n. & 2 & $21-23 ; 24^{\#}$ \\
\hline
\end{tabular}

DMPP: 1,1-dimethyl-4-phenylpiperazinium; DEXA: dexamethasone; i.p. intraperitoneally; i.n.: intranasally. ${ }^{*}$ : 10 min prior to metacholine test. 
calcium mobilisation. Cultures were maintained in the presence of smooth muscle cell basal growth medium (Cambrex Corporation). Cells $\left(2 \times 10^{6}\right)$ were plated in a $2.5 \mathrm{~cm}$ petri dish and incubated with $2.5 \mu \mathrm{M}$ Fura-2 for $30 \mathrm{~min}$ at $37^{\circ} \mathrm{C}$. Cells were either pre-treated or not pre-treated with $160 \mu \mathrm{M}$ DMPP for $24 \mathrm{~h}$ and stimulated with $10 \mathrm{nM}$ bradykinin. Changes in the concentration of intracellular $\mathrm{Ca}^{2+}$ ions were followed by Fura-2 fluorescence using the Imagemaster system (Photon Technology International, Monmouth Junction, NJ, USA) coupled to a Leica DM IRB Fluorescence microscope (Leica Canada Inc., St-Laurent, Quebec, Canada; $40 \times$ ). Excitation wavelengths were 353 and $374 \mathrm{~nm}$, respectively, and the emission wavelength was $510 \mathrm{~nm}$. The ratio between the fluorescence provoked by the 353 and the $374 \mathrm{~nm}$ excitation wavelengths was calculated and used as an intracellular calcium indicator.

\section{Statistics}

Statistical analyses for cellular findings and for each MCh dose administered were made using an ANOVA table followed by a Fisher's post-hoc test to determine statistical significance between groups (significant result $=\mathrm{p}<0.05$ ).
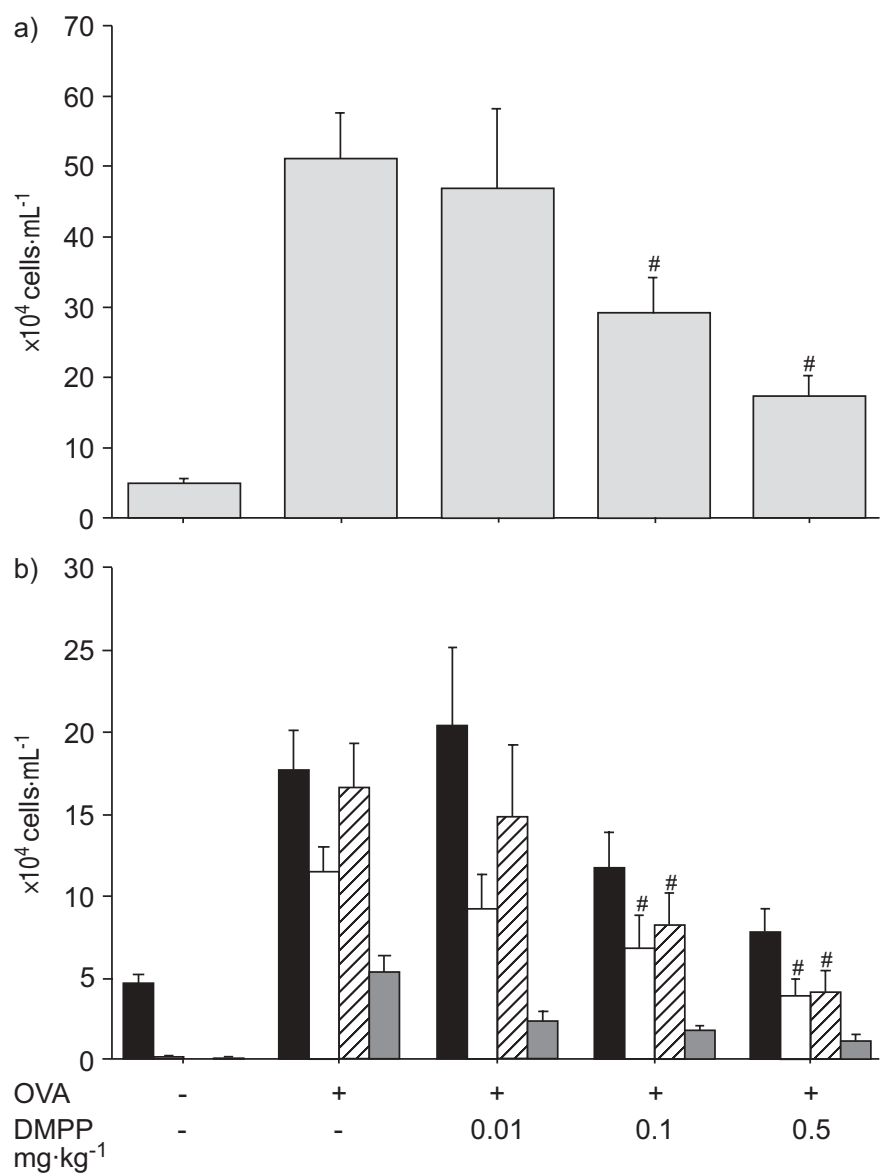

FIGURE 2. a) Effect of intraperitoneal 1,1-dimethyl-4-phenylpiperazinium (DMPP) administration on total cells, and b) differential counts in bronchoalveolar lavage of ovalbumin (OVA)-sensitised mice. The anti-inflammatory effect of DMPP was dose dependent and the accumulation of eosinophils and lymphocytes was reduced in treated mice compared with OVA sensitised and challenged mice. macrophages; $\square$ : lymphocytes; $\square$ : eosinophils; $\mathbb{Z}$ : neutrophils. $\#: p \leqslant 0.03$.

\section{RESULTS}

Effect of DMPP on BAL cells and OVA specific IgE levels in serum

DMPP at 0.1 and $0.5 \mathrm{mg} \cdot \mathrm{kg}^{-1}$ significantly reduced the total number of cells (fig. 2a; $p=0.03 ; n=8$ ), eosinophils (fig. $2 b$; $p \leqslant 0.02$ ) and lymphocytes (fig. $2 b ; p \leqslant 0.02$ ) in BAL compared with the untreated group of OVA sensitised mice. DMPP treatment during the challenges (days 21-23), sensitisation (days 1-20) or throughout the protocol (days 1-23) significantly reduced the number of total cells in the BAL (fig. 3; $\mathrm{p} \leqslant 0.009 ; \mathrm{n}=8)$ and the serum levels of OVA-specific IgE (fig. $4 ; \mathrm{p} \leqslant 0.02 ; \mathrm{n}=8$ ) compared with the nontreated group. DMPP given i.n. at $2.0 \mathrm{mg} \cdot \mathrm{kg}^{-1}$ also significantly reduced the total number of cells $(p=0.003 ; n=8$; fig. 5a), eosinophils $(p=0.0006)$ and lymphocytes $(p=0.004)$ in BAL (fig. 5b). It was as effective as $2.0 \mathrm{mg} \cdot \mathrm{kg}^{-1} \mathrm{DEXA}$.

\section{Histopathology}

Histopathology, presented in figure 6, shows a marked peribronchial, perivascular and parenchymal infiltration of inflammatory cells in the OVA group (fig. 6b) compared with control mice (fig. 6a). Mice treated with $2.0 \mathrm{mg} \cdot \mathrm{kg}^{-1} \mathrm{DMPP}$ (fig. 6c) showed decreased tissue infiltration by mononuclear cells and eosinophils compared with nontreated mice. DEXA showed a tendency to decrease tissue infiltration by inflammatory cells (fig. 6d), but results were not significantly different from those of nontreated mice. These results were confirmed by a reduction of the total histological score in DMPP treated mice compared with nontreated mice $(p=0.01$; $n=9$ mice per group; fig $6 e$ ).

\section{Effect of DMPP administration on airway resistance}

The effect of DMPP given at various times was tested on the increase in airway resistance in response to i.v. MCh. The administration of DMPP during the three days of the OVA

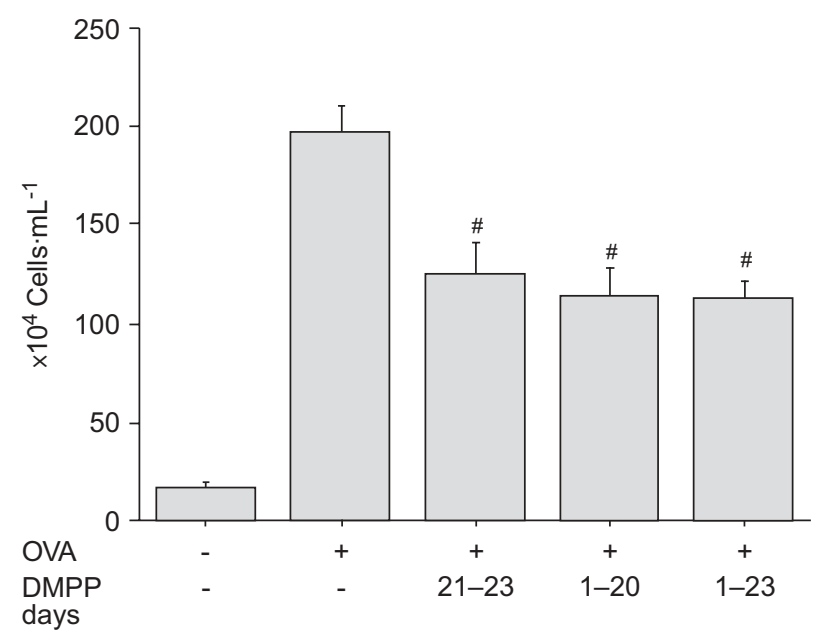

FIGURE 3. Effect of different timings of intraperitoneal 1,1-dimethyl-4phenylpiperazinium (DMPP) administration on total cell counts in bronchoalveolar lavage (BAL) of ovalbumin (OVA) challenged mice. Administration of DMPP during the challenges (days 21-23), the sensitisation to OVA only (days 1-20) or throughout the protocol (days 1-23) significantly reduced total cell counts in the BAL. ${ }^{*}: p \leqslant 0.009$ 


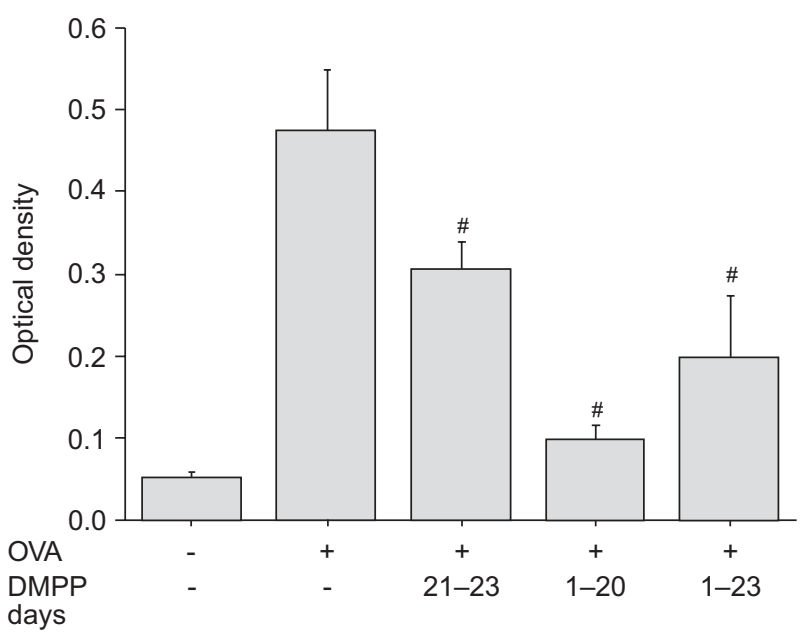

FIGURE 4. Effect of different timings of intraperitoneal 1,1-dimethyl-4phenylpiperazinium (DMPP) administration on ovalbumin (OVA)-specific immunoglobulin (Ig) E levels. Results are expressed as arbitrary optical density levels. Compared with nontreated mice, DMPP reduced the serum levels of OVA-specific $\lg E$ in mice treated during the challenges (days 21-23; $p=0.001$ ), during the sensitisation (days $1-20 ; p=0.02$ ) and throughout the protocol (days 1-23; $\mathrm{p}=0.04)$. \#: significant results compared with OVA challenged and nontreated mice.

challenges did not significantly alter the response to MCh (data not shown). The i.n. administration of DMPP $10 \mathrm{~min}$ before the MCh challenge on day 24 had a significant inhibitory effect on MCh-induced airway resistance compared with nontreated controls. (fig. 7a; $\mathrm{p}<0.05$ for MCh doses $>3.5 \mathrm{mg} \cdot \mathrm{kg}^{-1} ; \mathrm{n}=4$ ). Treatment during the 3 days of OVA challenges and $10 \mathrm{~min}$ before MCh administration also had a significant protective effect on the increase in airway resistance (fig. $7 b ; p<0.05$ for MCh doses $>3.5 \mathrm{mg} \cdot \mathrm{kg}^{-1} ; \mathrm{n}=4$ ). In contrast to DMPP, DEXA administered during the 3 days of the OVA challenges and $10 \mathrm{~min}$ before the $\mathrm{MCh}$ did not significantly reduce the response to $\mathrm{MCh}$ (fig. 8).

\section{Intracellular calcium mobilisation in BSMCs}

Stimulation of isolated smooth muscle cells with bradykinin provoked a quick intracellular calcium mobilisation which was delayed by $236 \pm 31$ s by DMPP $(\mathrm{p}<0.0001 ; \mathrm{n}=12)$. DMPP also reduced the peak intensity of the response by $43.4 \pm 14.9 \%$ compared with nontreated cells $(n=9 ; p=0.03$; fig. 9).

\section{DISCUSSION}

The present study was carried out to verify if DMPP, a nAChR agonist, could have a protective effect on the development of airway inflammation and responsiveness in a murine model of asthma, and to evaluate possible mechanisms of action. The results support the hypothesis that these agonists have a protective effect on airway inflammation and responsiveness and that this effect may be related to antigen sensitisation and calcium metabolism. Taken together, these results confirm other published data by the current authors and others $[8,9$, $10,21]$.

It is important to separate the specific anti-inflammatory effects of nicotinic agonists, such as nicotine, from the overall
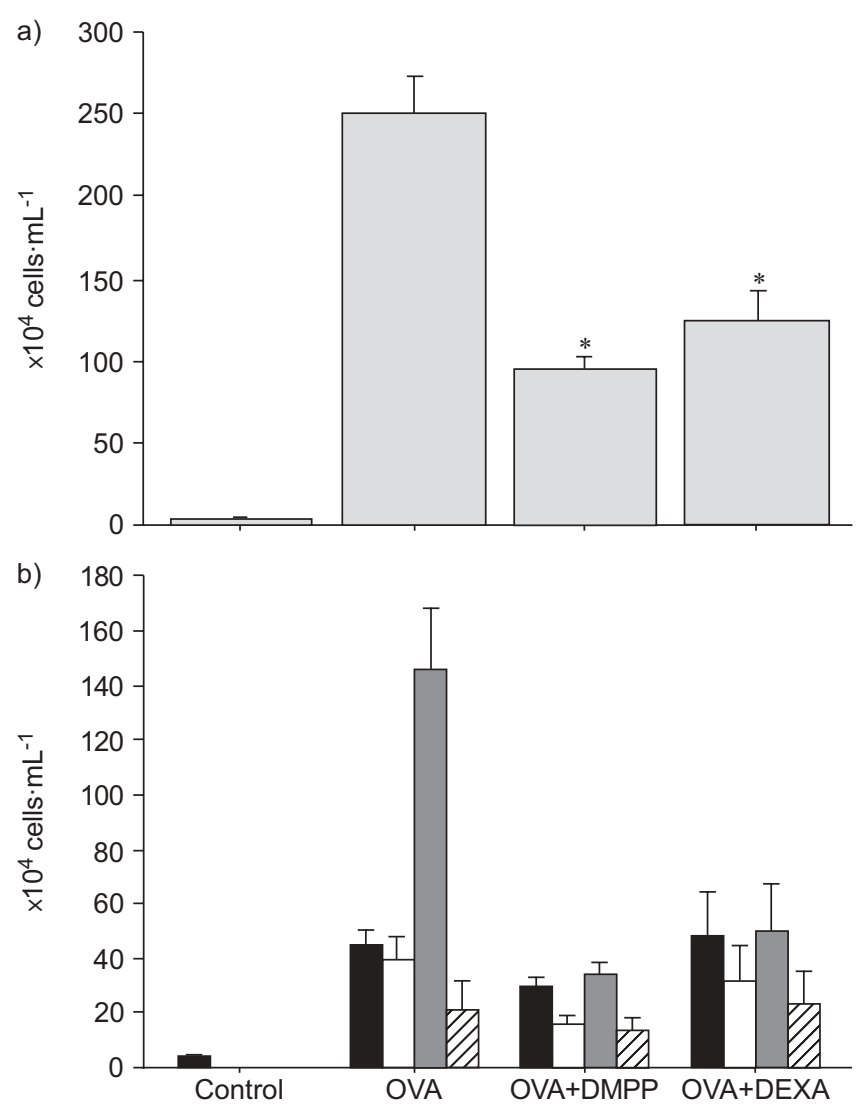

FIGURE 5. a) Total cell accumulation, and b) differential cell counts in the bronchoalveolar lavage (BAL) of intranasally 1,1-dimethyl-4-phenylpiperazinium (DMPP) and dexamethasone (DEXA) treated mice, $2.0 \mathrm{mg} \cdot \mathrm{kg}^{-1}$. Administration of either DMPP or DEXA intranasally significantly reduced the total cell and eosinophil counts in the BAL. DMPP also reduced lymphocyte accumulation in BAL, while DEXA had no effect. $\mathbf{\square}$ : macrophages; $\square$ : lymphocytes; $\mathbf{\square}$ : eosinophils; $\mathbb{Z}$ : neutrophils. *: $p \leqslant 0.05$.

immunosuppressive effect of smoking. The present authors do not wish to suggest that cigarette smoking could be beneficial for asthmatic patients. However, there is evidence in the literature that the use of nicotinic agonists could be efficient in treating some inflammatory diseases $[8,9,10]$. As nicotine crosses the blood-brain barrier and, thus, causes addiction it could not be used as a potential compound to treat asthma or any other chronic diseases. DMPP and possibly other hydrosoluble compounds that do not cross the blood-brain barrier are quite different from nicotine and, therefore, have potential benefits in the treatment of asthma.

DMPP was administered i.n. so as to test a direct route of administration. This route results in absorption by the nasal capillaries which drain into the superior vena cava. Blood then passes into the pulmonary circulation before passing through the liver [22]. However, most of what is given i.n. is swallowed by the animal, absorbed by the digestive tract and circulated through the portal system through the liver before passing to the lungs. The present authors, therefore, believe that part of the anti-inflammatory effect observed in i.n. DMPP-treated animals could come from the systemic effect of DMPP, which was absorbed in the digestive tract. 

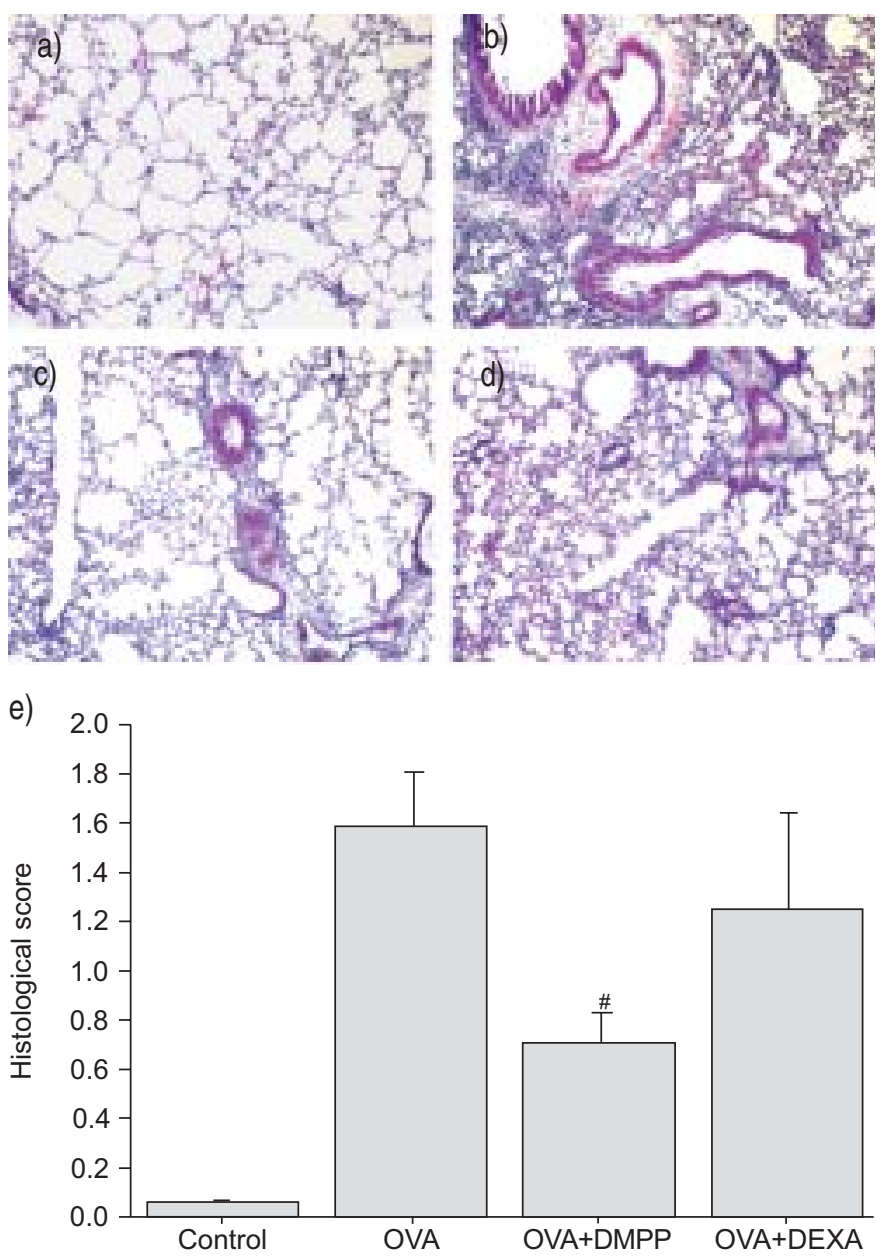

FIGURE 6. Histopathology of a) control (saline); b) nontreated mice (ovalbumin (OVA)); c) $2.0 \mathrm{mg} \cdot \mathrm{kg}^{-1}$ 1,1-dimethyl-4-phenylpiperazinium (DMPP) treated mice (OVA+DMPP); and d) $2.0 \mathrm{mg} \cdot \mathrm{kg}^{-1}$ dexamethasone (DEXA) treated mice (OVA+DEXA). OVA instillation induced a marked peribronchial, perivascular and parenchymal infiltration by inflammatory cells compared with control mice. DMPP administration significantly reduced this infiltration. e) Total histological score graded on a scale from 0-4. 0: no inflammatory cells; 1: <10\%; 2: 10-25\%; 3: 25$50 \%$; and 4: $>50 \%$. Score was significantly reduced in DMPP treated mice (total score: $0.70 \pm 0.12$ ), but not in DEXA-treated mice (total score: $1.24 \pm 0.40$ ) compared with nontreated mice (total score: $1.58 \pm 0.23$ ). $\#: p=0.01 ; n=8$.

The fact that the response of mice to OVA sensitisation and challenges was different from one protocol to the other could be due to a number of factors. The effectiveness of i.n. administration is dependant on the level of anaesthesia which was not technically reproducible between protocols. Also, protocols 1 to 6 were conducted separately using a new OVA protein solution each time; there can be variations in the OVA anti-genicity between different OVA preparations.

As previously reported with nicotinic agonists, the present results also show a marked anti-inflammatory effect of DMPP equalling that of DEXA. As for previous studies [23-26], a high dose of DEXA was given $\left(2.0 \mathrm{mg} \cdot \mathrm{kg}^{-1}\right)$. This is a much higher dose of corticosteroid than is usually given in the treatment of even the most severe cases of human asthma [16]. Still, the $2.0 \mathrm{mg} \cdot \mathrm{kg}^{-1}$ of i.n. DMPP was as effective in reducing the
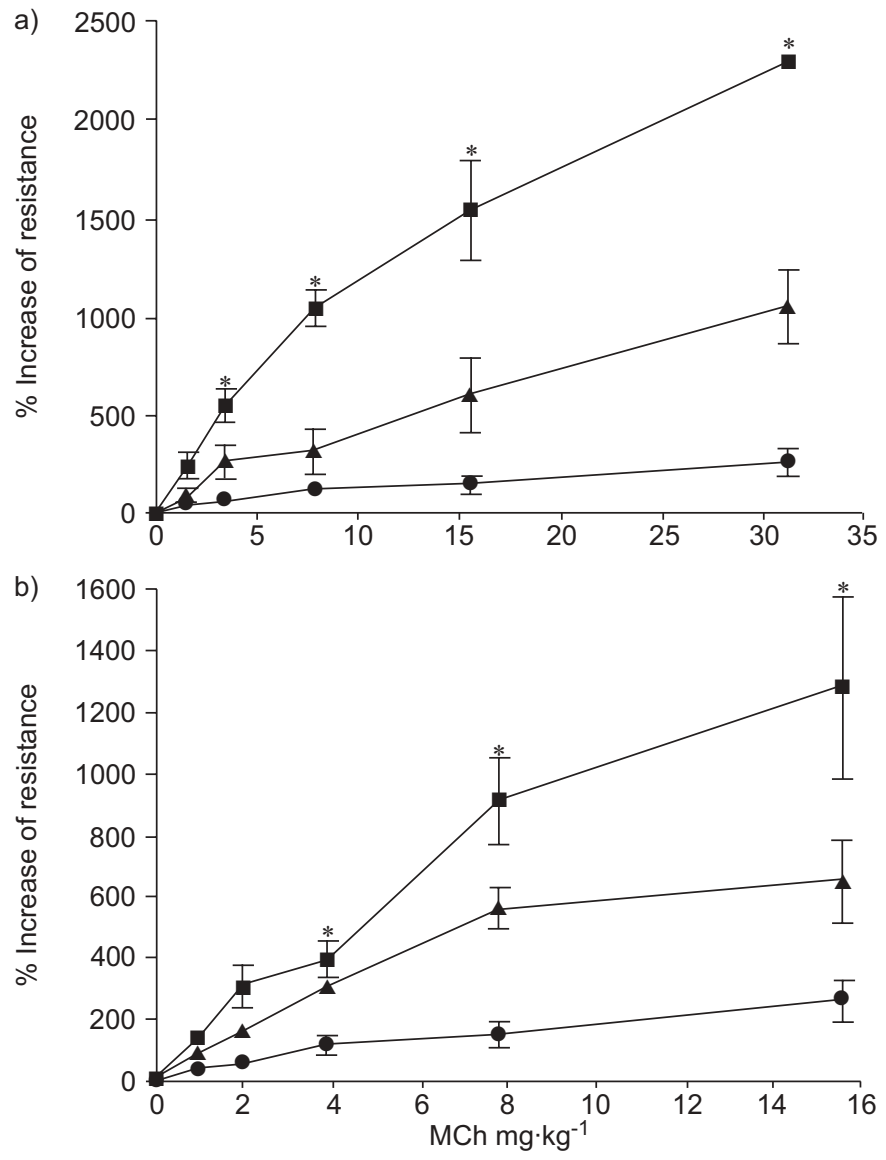

FIGURE 7. Airway resistance in response to a metacholine (MCh) challenge after different timings of 1,1-dimethyl-4-phenylpiperazinium (DMPP) treatment. a) Single administration $10 \mathrm{~min}$ before the MCh challenge, and b) DMPP administrations on days 21, 22, 23 and 24; 10 min before the MCh challenge. DMPP significantly reduced the airway response compared with nontreated mice. ovalbumin (OVA); $\mathbf{\Delta}$ : OVA+DMPP; $\bullet$ : controls. ${ }^{*}$ : $p<0.05$.

number of total cells and eosinophils in the BAL as this high dose of corticosteroids. Furthermore, DEXA failed to reduce the number of lymphocytes in the BAL and the total histological score while DMPP did. The fact that DEXA only showed a tendency to decrease the total histological score is surprising and could be due to some intra-group variability or to the fact that $2.0 \mathrm{mg} \cdot \mathrm{kg}^{-1}$ of DEXA was used while other studies used even higher doses [25, 27].

The effects of nicotinic agonists on smooth muscles are not clear from the literature. Some studies showed smooth muscle relaxation [28], others showed contraction [29]. One study showed that DMPP reduces the bronchomotor tone in cats [19]. The current results clearly support a bronchoprotective effect in the mice model. This bronchoprotection, i.e. decreased hyperresponsiveness to $\mathrm{MCh}$, does not seem to be solely due to the effects of DMPP on inflammation since the anti-inflammatory effects of DEXA and the administration of DMPP during the 3 days of the OVA challenges (data not shown) did not induce a similar bronchoprotection. Results obtained with the i.n. administration $10 \mathrm{~min}$ before the $\mathrm{MCh}$ test confirm a direct smooth muscle relaxant effect of the drug. This direct effect 


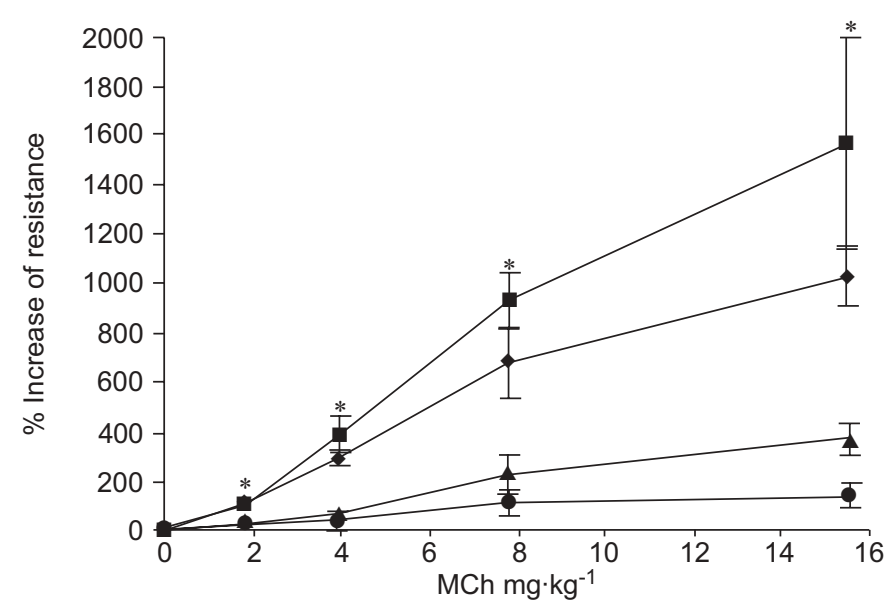

FIGURE 8. Comparison of the effect of $2.0 \mathrm{mg} \cdot \mathrm{kg}^{-1}$ intranasal 1,1-dimethyl-4phenylpiperazinium (DMPP) and dexamethasone (DEXA) on the increase in airway resistance in response to a metacholine (MCh) challenge. DMPP and DEXA were administered during the 3 days of the OVA challenges, and 10 min before the MCh challenge. DMPP significantly reduced airway resistance compared with both nontreated mice and DEXA-treated mice. $\mathbf{a}$ : ovalbumin (OVA); $\mathbf{\Lambda}$ : OVA+DMPP; controls; : OVA+DEXA. *: $p<0.05$.

was observed for as long as $4 \mathrm{~h}$ after the DMPP administration (data not shown).

Different timings of i.p. administration were tested in order to verify if DMPP could inhibit the OVA-induced sensitisation, and if repeated DMPP administration would prevent inflammation induced by the OVA challenge. The fact that DMPP administration (at $0.5 \mathrm{mg} \cdot \mathrm{kg}^{-1}$, given from day 1-20 (sensitisation) without treatment during the OVA challenges) significantly reduced cell counts in BAL suggests that DMPP partially blocked the sensitisation to OVA. This hypothesis is further supported by the reducing effect of DMPP on OVAspecific IgE serum levels. This is very interesting since the sensitisation to allergens precedes the development of allergic asthma [1]. Since DMPP treatment throughout the protocol (both sensitisation and challenge) had the same antiinflammatory effect as the treatment during the challenges alone, the continuous treatment with DMPP does not seem to cause a desensitisation of the nAChRs.

The mechanisms underlying the modulatory effect of DMPP are still unknown. Since the bronchospasm was induced by $\mathrm{MCh}$ and that the bronchoprotective effect was observed as fast as 10 min after DMPP administration, this drug must act directly on airway smooth muscle and not only via its antiinflammatory effects. One of the major steps of smooth muscle cell contraction is intracellular calcium mobilisation [30]. The fact that DMPP delayed and reduced the intracellular calcium increase provoked by bradykinin could explain, at least in part, the in vivo bronchoprotective effects of DMPP that were observed in the present model. The exact mechanisms explaining these observations on calcium mobilisation are still unknown. Some studies have demonstrated that nicotine, another nicotinic agonist, could deplete intracellular calcium stores in lymphocytes [13]. Depletion of these stores could lead to a delayed and reduced intracellular

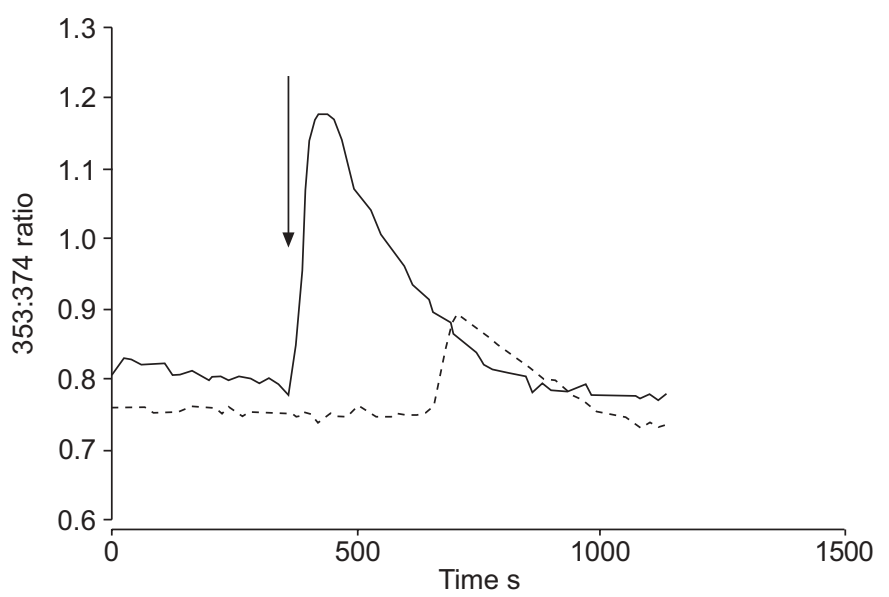

FIGURE 9. Effect of 1,1-dimethyl-4-phenylpiperazinium (DMPP; $160 \mu \mathrm{M} ; 24 \mathrm{~h}$ ) on the intracellular calcium rise provoked by the addition of $10 \mathrm{nM}$ bradykinin (arrow) after 10 min of recording. Stimulation of the G-protein coupled bradykinin receptor provoked a quick calcium mobilisation. DMPP treatment delayed and reduced the intensity of the response to bradykinin. This result is representative of three different experiments, each of which consisted of recording the intracellular calcium increase in three to five different cells. _- : untreated; - - - -: DMPP treated.

calcium increase. The downregulating effect of nicotinic agonists on overall calcium mobilisation could be responsible for both the anti-inflammatory and bronchoprotective effects of these molecules.

DMPP can stimulate every $\alpha$-subunit of nAChR. Further studies will be needed to verify which specific subunit is involved in the effects that were observed. Previous results obtained in the authors' laboratory (with the use of mecamylamine and haexamethonium) have shown that both the antiinflammatory and smooth muscle relaxing effects of DMPP are selective to activation of nicotinic receptors [31, 32]. The identification of the subunits involved in both the antiinflammatory and bronchoprotective effects could lead to the development of more specific agonists for a more effective treatment of asthma.

\section{CONCLUSION}

In conclusion, 1,1-dimethyl-4-phenylpiperazinium has potent anti-inflammatory and bronchoprotective effects in the mouse model of asthma. Inflammation and airway hyperresponsiveness are two major components of asthma. This molecule, and potentially other nicotinic agonists targeting specific nicotinic acetylcholine receptor subtypes, could, therefore, provide a new therapeutic approach of asthma.

\section{ACKNOWLEDGEMENTS}

The authors would like to thank the Institut de Recherche Robert-Sauvé en Santé et Sécurité au Travail (Montreal, Canada) and the Canadian Institute for Health Reasearch (Ottawa, Canada) for financial support. They would also like to thank M. Fournier for help with the pathology studies, M. Laviolette for providing the BSMC cell line and M. Olivier (McGill University, Montreal, Canada) for donating the Biotinylated-ovalbumin. 


\section{REFERENCES}

1 Hogg JC. The pathology of asthma. APMIS 1997; 105 735-745.

2 Walls AF, He S, Buckley MG, McEuen AR. Roles of the mast cell and basophil in asthma. Clin Exp Allergy Reviews 2001; 1: 68-72.

3 Sampson AP. Eosinophils: provokers or bystanders in asthma? Clin Exp Allergy Reviews 2001; 1: 73-76.

4 Anderson GP. Lymphocytes: arbitrers of airway inflammation. Clin Exp Allergy Reviews 2001; 1: 80-84.

5 Talib S, Okarma TB, Lebkowski JS. Differential expression of human nicotinic acetylcholine receptor alpha subunit variants in muscle and non-muscle tissues. Nucleic Acids Res 1993; 21: 233-237.

6 Hiemke C, Stolp M, Reuss S, et al. Expression of alpha subunit genes of nicotinic acetylcholine receptors in human lymphocytes. Neurosci Lett 1996; 214: 171-174.

7 Maus AD, Pereira EF, Karachunski PI, et al. Human and rodent bronchial epithelial cells express functional nicotinic acetylcholine receptors. Mol Pharmacol 1998; 54: 779-788.

8 Mabley JG, Pacher P, Southan GJ, Salzman AL, Szabo C. Nicotine reduces the incidence of type I diabetes in mice. $J$ Pharmacol Exp Ther 2002; 300: 876-881.

9 Blanchet MR, Israel-Assayag E, Cormier Y. Inhibitory effect of nicotine on experimental hypersensitivity pneumonitis in vivo and in vitro. Am J Respir Crit Care Med 2004; 169: 903-909.

10 Sandborn WJ. Nicotine therapy for ulcerative colitis: a review of rationale, mechanisms, pharmacology, and clinical results. Am J Gastroenterol 1999; 94: 1161-1171.

11 Goerig M, Ullrich V, Schettler G, Foltis C, Habenicht A. A new role for nicotine: selective inhibition of thromboxane formation by direct interaction with thromboxane synthase in human promyelocytic leukaemia cells differentiating into macrophages. Clin Investig 1992; 70: 239-243.

12 Zhang S, Petro TM. The effect of nicotine on murine CD4 T cell responses. Int J Immunopharmacol 1996; 18: 467-478.

13 Kalra R, Singh SP, Savage SM, Finch GL, Sopori ML. Effects of cigarette smoke on immune response: chronic exposure to cigarette smoke impairs antigen-mediated signaling in T cells and depletes IP3-sensitive Ca (2+) stores. J Pharmacol Exp Ther 2000; 293: 166-171.

14 Savage SM, Donaldson LA, Cherian S, Chilukuri R, White VA, Sopori ML. Effects of cigarette smoke on the immune response. II. Chronic exposure to cigarette smoke inhibits surface immunoglobulin-mediated responses in B cells. Toxicol Appl Pharmacol 1991; 111: 523-529.

15 Deurloo DT, van Esch BC, Hofstra CL, Nijkamp FP, van Oosterhout AJ. CTLA4-IgG reverses asthma manifestations in a mild but not in a more "severe" ongoing murine model. Am J Respir Cell Mol Biol 2001; 25: 751-760.

16 Katzung BG. Basic and clinical pharmacology. New York, McGraw-Hill/Appleton and Lange, 1998.

17 Fecho K, Maslonek KA, Dykstra LA, Lysle DT. Alterations of immune status induced by the sympathetic nervous system: immunomodulatory effects of DMPP alone and in combination with morphine. Brain Behav Immun 1993; 7: 253-270.
18 Matsunaga $\mathrm{K}$, Klein TW, Friedman $\mathrm{H}$, Yamamoto $\mathrm{Y}$. Involvement of nicotinic acetylcholine receptors in suppression of antimicrobial activity and cytokine responses of alveolar macrophages to Legionella pneumophila infection by nicotine. J Immunol 2001; 167: 6518-6524.

19 Thompson DC, Altiere RJ, Diamond L. Nicotinic agonist modulation of feline bronchomotor tone. Clin Exp Pharmacol Physiol 1990; 17: 83-97.

20 Hylkema MN, Timens W, Luinge M, Van Der WN, Hoekstra MO. The effect of bacillus Calmette-Guerin immunization depends on the genetic predisposition to Th2-type responsiveness. Am J Respir Cell Mol Biol 2002; 27: 244-249.

21 Melgert BN, Postma DS, Geerlings M, et al. Short-term smoke exposure attenuates ovalbumin-induced airway inflammation in allergic mice. Am J Respir Cell Mol Biol 2004; 30: 880-885.

22 Guthrie SK, Zubieta JK, Ohl L, et al. Arterial/venous plasma nicotine concentrations following nicotine nasal spray. Eur J Clin Pharmacol 1999; 55: 639-643.

23 Hamelmann E, Cieslewicz G, Schwarze J, et al. Antiinterleukin 5 but not anti-IgE prevents airway inflammation and airway hyperresponsiveness. Am J Respir Crit Care Med 1999; 160: 934-941.

24 Birrell MA, Battram CH, Woodman P, McCluskie K, Belvisi MG. Dissociation by steroids of eosinophilic inflammation from airway hyperresponsiveness in murine airways. Respir Res 2003; 4: 3.

25 Trifilieff A, El Hashim A, Bertrand C. Time course of inflammatory and remodeling events in a murine model of asthma: effect of steroid treatment. Am J Physiol Lung Cell Mol Physiol 2000; 279: L1120-L1128.

26 Eum SY, Maghni K, Hamid Q, et al. Inhibition of allergic airways inflammation and airway hyperresponsiveness in mice by dexamethasone: role of eosinophils, IL-5, eotaxin, and IL-13. J Allergy Clin Immunol 2003; 111: 1049-1061.

27 Hellings PW, Kasran A, Liu Z, et al. Interleukin-17 orchestrates the granulocyte influx into airways after allergen inhalation in a mouse model of allergic asthma. Am J Respir Cell Mol Biol 2003; 28: 42-50.

28 Borjesson L, Nordgren S, Delbro DS. DMPP causes relaxation of rat distal colon by a purinergic and a nitrergic mechanism. Eur J Pharmacol 1997; 334: 223-231.

29 De Man JG, Moreels TG, De Winter BY, et al. Disturbance of the prejunctional modulation of cholinergic neurotransmission during chronic granulomatous inflammation of the mouse ileum. Br J Pharmacol 2001; 133: 695-707.

30 Kuo KH, Dai J, Seow CY, Lee $\mathrm{CH}$, van Breemen C. Relationship between asynchronous $\mathrm{Ca} 2+$ waves and force development in intact smooth muscle bundles of the porcine trachea. Am J Physiol Lung Cell Mol Physiol 2003; 285: L1345-L1353.

31 Israel-Assayag E, Ferland C, Blanchet M-R, Laviolette M, Cormier Y. Down regulation of blood eosinophil transmigration by nicotinic receptor agonists in vitro. Am J Respir Crit Care Med 2003; 167: A754.

32 Dorion G, Israel-Assayag E, Blanchet M-R, Cormier Y. Effect of a nicotinic receptor agonist on mouse tracheal smooth muscle responsiveness. Am J Respir Crit Care Med 2003; 167: A876. 